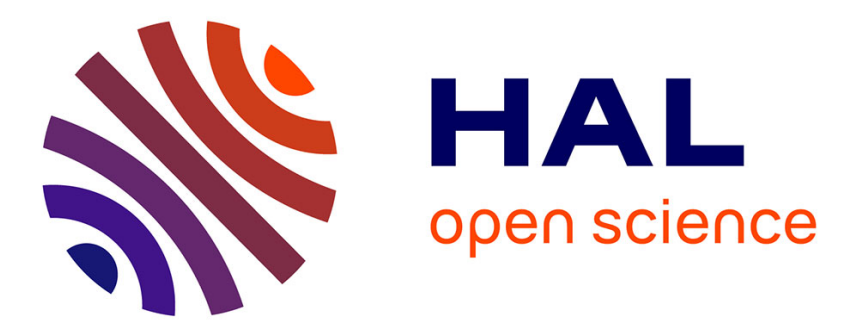

\title{
Effects of dietary crude protein levels on development, antioxidant status, and total midgut protease activity of honey bee (Apis mellifera ligustica)
}

Chengcheng Li, Baohua Xu, Yuxi Wang, Qianqian Feng, Weiren Yang

\section{- To cite this version:}

Chengcheng Li, Baohua Xu, Yuxi Wang, Qianqian Feng, Weiren Yang. Effects of dietary crude protein levels on development, antioxidant status, and total midgut protease activity of honey bee (Apis mellifera ligustica). Apidologie, 2012, 43 (5), pp.576-586. 10.1007/s13592-012-0126-0 . hal01003648

\section{HAL Id: hal-01003648 \\ https://hal.science/hal-01003648}

Submitted on 1 Jan 2012

HAL is a multi-disciplinary open access archive for the deposit and dissemination of scientific research documents, whether they are published or not. The documents may come from teaching and research institutions in France or abroad, or from public or private research centers.
L'archive ouverte pluridisciplinaire HAL, est destinée au dépôt et à la diffusion de documents scientifiques de niveau recherche, publiés ou non, émanant des établissements d'enseignement et de recherche français ou étrangers, des laboratoires publics ou privés. 


\title{
Effects of dietary crude protein levels on development, antioxidant status, and total midgut protease activity of honey bee (Apis mellifera ligustica)
}

\author{
Chengcheng $\mathrm{LI}^{1}$, Baohua $\mathrm{Xu}^{1}$, Yuxi $\mathrm{WANG}^{2}$, Qianqian $\mathrm{FeNG}^{1}$, Weiren YANG ${ }^{1}$ \\ ${ }^{1}$ College of Animal Science and Technology, Shandong Agricultural University, Tai'an, Shandong, \\ People's Republic of China 271018 \\ ${ }^{2}$ Agriculture and Agri-Food Canada, Lethbridge Research Centre, PO Box 3000, Lethbridge, \\ Alberta, Canada T1J 4B1
}

Received 2 November 2011 - Revised 4 January 2012 - Accepted 23 January 2012

\begin{abstract}
The effects of different levels of dietary crude protein on the development, antioxidant enzymatic activity, and total midgut protease activity of honey bees were investigated in the study. A total of 30 colonies of bees with sister queens were used in the test. Dietary treatments were pure rape pollen (Control) and pollen substitutes (PS) with crude protein (CP) levels at 15\%,20\%, 25\%, 30\%, and 35\% (designated as PS15, PS20, PS25, PS30, and PS35), respectively. We compared the effects of these diets on honey bees by measuring diet consumption, bee development (egg hatch, pupation success, and pupal weight), and the protein content of emergent adult bees, their antioxidant status and the activity of their midgut digestive proteases. Bees consumed significantly more $(P<0.001)$ natural pollen than any PS, and bees fed PS had similar diet consumption over the entire experimental period. However, the total protein intake was varied $(P<0.05)$. PS with a protein level about $30 \%$ was recognized as excellent quality diet for maximum body weight, highest protein content and antioxidant enzymatic activity, and PS with a protein rate about $35 \%$ exerted the greatest effect on increasing percentage of hatch and percentage of pupation. All these results indicate that PS appeared to be a valuable proteinaceous food approximated to the pollen, and $30 \sim 35 \%$ of dietary protein level was optimal to maintain the colony development.
\end{abstract}

Apis mellifera ligustica / dietary crude protein levels / development / antioxidant status / total midgut protease activity

\section{INTRODUCTION}

Protein is one of the essential nutrients for the normal growth and development of honey bees (Moritz and Crailsheim 1987; Schmidt et al. 1995). It has been shown that worker bees start to consume pollen just a few hours after emerging (Hagedorn and Moeller 1967; Dietz 1969) and that an adequate provision of proteins especially during the first 2 weeks after emer-

Corresponding author: W. Yang, wryang211@163.com; wryang@sdau.edu.cn Manuscript editor: Klaus Hartfelder gence is required to sustain their normal growth and development, and for them to be able to rear larvae (Haydak 1970). Pollen is a natural and protein-rich food source for honey bees to obtain their required proteins (Schäfer et al. 2006). However, the availability of pollen depends on the plants' growing seasons during the year. In addition, the pollen may contain spores of pathogens that cause diseases such as American foulbrood (Rothenbuhler 1964; Spivak and Reuter 2001; Hornitzky 2010) or chalkbrood (Gilliam et al. 1983; Spivak and Reuter 2001; Flores et al. 2005) in bees and/or larvae. Therefore, artificial protein diets have been 
studied as pollen substitute (or pollen supplement (PS)) to replace the natural pollen in the past couple decades. However, the majority of these studies were conducted to assess the effect of artificial protein diets on just few parameters such as amount of brood in the colony and colony population (Doull 1973; Herbert and Shimanuki 1982; Mattila and Otis 2006). It has been reported that feeding artificial protein-rich diets has enhanced the growth of bee colonies in the spring or when the availability of pollen was limited (e.g., Schmidt et al. 1995; Somerville and Nicol 2006). However, an ideal PS has not been developed due to the lack of basic information about the nutritional requirements of the honey bee.

Worker quality can be evaluated by several indicators, with longevity being the most common one influenced by protein status (Knox et al. 1971; Schmidt et al. 1987; Burgess et al. 1996; Chen 2001). Previous research has demonstrated that insect longevity was inversely correlated with the antioxidant defenses (Arking et al. 2000; Phillips et al. 1989). And whether antioxidant status of honey bee can be influenced by dietary protein level has not been studied before. Total protease activity in honey bee midgut is also an important parameter related to protein digestion. However, no research has concerned the relationship between total protease activity in honey bee midgut and dietary protein. So, the objective of the study was to systematically evaluate the effects of different dietary protein concentrations on bee development, the antioxidant status of newly emerged bees, and total protease activity in their midguts.

\section{MATERIAL AND METHODS}

\subsection{Experimental design, bees, and management}

The study used Apis mellifera maintained in two deep Langstroth hive bodies at the Apiary of the Shandong Agricultural University. Thirty colonies of bees with sister queens from the same breeding line were randomly allocated to six groups (five colonies per group). One group was fed pure rape pollen only (Control) and others were fed the PS diets (PS) with crude protein (CP) levels (dry matter basis) at $15 \%$, $20 \%, 25 \%, 30 \%$, and $35 \%$ (designated as PS 15 , PS20, PS25, PS30, and PS35), respectively. The treatments were arranged as complete randomized design.

The PS used were mixtures of corn meal, soybean meal and corn gluten meal that were all processed into particle sizes of $0.15 \mathrm{~mm}$ (Somerville 2000). With the exception of different CP levels, the nutrient compositions of the PS were similar to that of rape pollen (Table I). Samples of the PS, as well as rape pollen, were analyzed to determine total CP (total, $N \times 6.25$ ) according to the Kjeldahl N procedure. All diets were made in one batch and were stored in separate containers in shade prior to feeding.

\subsection{Field study}

At the beginning of the study, combs with stored natural pollen were replaced with empty ones and cupped brood combs without workers were exchanged among colonies. This meant that all experimental colonies contained 12 frames with a similar number of workers and broods. Colonies were adapted to each diet for 8 days first, then, the experiment was conducted for 33 days between August and September. Pollen traps were fitted to hives at all stages to remove pollen brought in by foragers. All the diets were processed into patties $(500 \mathrm{~g})$ consisting of rape pollen or one of PS (40\%), 50\% sucrose, and $10 \%$ honey by weight. Patties were all wrapped with a plastic film at the top, which significantly reduced the water loss. The per-weighed patty for each colony was then flattened between sheets of waxed paper and placed on the top of the frames over the brood cluster weekly. The bees had access to water and the patty ad libitum, but no other sources of water and food were available.

\subsection{Measurement of bee population and consumption}

The population of adult bee was recorded every 11 days, by estimating the area of frame covered with bees (one frame with two sides fully covered by single-layer bees was designated as 1-frame, about 2,500 bees. One frames partly, for instance, half covered by single-layer bees was designated as 0.5 -frame, about 
Table I. Diet formulation and compositions (in percent).

\begin{tabular}{lcccccc}
\hline Item & \multicolumn{2}{l}{ Treatments } & & & & \\
\cline { 2 - 6 } & Control & PS15 & PS20 & PS25 & PS30 & PS35 \\
\cline { 2 - 6 } & & & & & & \\
Ingredients (\%) & 0 & 37.80 & 33.00 & 22.20 & 22.80 & 16.50 \\
Corn & 0 & 11.20 & 15.30 & 33.80 & 48.10 & 58.20 \\
Soybean meal & 0 & 13.59 & 20.50 & 16.43 & 13.20 & 15.00 \\
Corn gluten meal & 0 & 36.33 & 30.11 & 26.61 & 15.07 & 9.58 \\
Sucrose & 99.98 & 0 & 0 & 0 & 0 & 0 \\
Rape pollen & 0 & 0.47 & 0.48 & 0.41 & 0.33 & 0.29 \\
Calcium hydrogen phosphate & 0 & 0.29 & 0.29 & 0.23 & 0.14 & 0.11 \\
Calcium carbonate & 0 & 0.30 & 0.30 & 0.30 & 0.30 & 0.30 \\
Premix & 0.02 & 0.02 & 0.02 & 0.02 & 0.02 & 0.02 \\
Antioxidant & b & 100.00 & 100.00 & 100.00 & 99.96 & 100.00 \\
Total & 100.00 & & & & & \\
Calculated composition & 17.50 & 17.25 & 17.47 & 17.51 & 17.45 & 17.58 \\
Gross energy (MJ/kg) & 23.05 & 15.18 & 20.16 & 25.35 & 30.07 & 34.95 \\
CP (\%) & 0.38 & 0.38 & 0.39 & 0.38 & 0.37 & 0.37 \\
Calcium (\%) & 0.19 & 0.19 & 0.20 & 0.21 & 0.21 & 0.20 \\
Phosphorus (\%) & & & & & & \\
\hline
\end{tabular}

${ }^{\text {a }}$ Provided per kilogram of diet: vitamin A, 5,000 IU; vitamin $\mathrm{D}_{3}, 2,000 \mathrm{IU}$; vitamin E, $240 \mathrm{mg}$; vitamin C, $265.4 \mathrm{mg}$; thiamine, $5.4 \mathrm{mg}$; riboflavin, $6 \mathrm{mg}$; pyridoxine, $7 \mathrm{mg}$; niacin, $18 \mathrm{mg}$; folic acid, $20 \mathrm{mg}$; and inositol, $318 \mathrm{mg}$.

${ }^{\mathrm{b}}$ Antioxidant is used to prevent the powder from deteriorating in summer.

1,250 bees.). Measurements of all these 12 frames with adult bees were summed for each colony. At the beginning of the 33-day experiment, we adjusted the population to 11-frame per colony (approximate 27,500 bees), but the population of adult bee slightly varied during the 33-day period, thus we calculated the diet consumption of 1-frame $(2,500$ bees) during each 11-day period (total 11-day diet consumption divided by the population of adult bees). And the data used for statistical analysis were the sum of these three times.

\subsection{Measurement of development parameters}

After 8-day adaption to experimental conditions, each queen was then confined on an empty comb enclosed in a queen excluder for $24 \mathrm{~h}$ in order to obtain bees of uniform age. After the queens were released, large quantities of eggs laid on the combs were obtained, from which 400 eggs (200 from each side of the comb) were labeled using a wire grid and the numbers of labeled eggs that hatched after 3-day period were recorded. Once the first sealed brood (pupa) appeared, the larvae were observed every $12 \mathrm{~h}$ until all of them had been sealed into their cells and numbers of pupae were recorded. On day six of the pupal period, ten pupae were sampled from each colony, placed into a $10-\mathrm{mL}$ centrifuge tube and weighed. The procedure was repeated thrice for each colony and three weights were averaged to determine the weight of pupa. The sample weighing procedure was also utilized to determine the body weight of worker at emergence when the insect emerged as an imago.

\subsection{Determination of protein content and antioxidant status of workers}

Fifteen workers from each colony were collected at adult emergence and were stored at $-80^{\circ} \mathrm{C}$ until they were analyzed for protein content and antioxidant enzyme activity. 
Upon the analysis, five frozen workers as one sample were homogenized with saline $(0.9 \%$ solution, $w / v)$ at the ratio of $1: 9$ at $4^{\circ} \mathrm{C}$ for $30 \mathrm{~s}$. The mixture was then centrifuged $\left(4^{\circ} \mathrm{C}\right)$ at $3,000 \mathrm{rpm}$ for $5 \mathrm{~min}$, and aliquot of the supernatant was used for protein determination using a Bradford Protein Assay Kit A045 (Institute of Biological Engineering of Naijing Jiancheng, Nanjing, China). The procedure was repeated thrice for each colony and the averages were used for statistical analysis.

The supernatants obtained from the procedure described above were also used for determination of antioxidant status. Total superoxide dismutase (T-SOD) activity was assayed using a T-SOD Assay Kit A001 (Institute of Biological Engineering of Naijing Jiancheng, Nanjing, China). The methodology used in the kit is the nitrite method described by Oyanagui (1984). The method for superoxide dismutase (SOD) measurement is based on the ability of the enzyme to inhibit the formation of nitrite from oxidation of hydroxylamine in the presence of superoxide anion $\left(\mathrm{O}_{2}^{-}\right.$; produced by the xanthine and xanthine oxidase system). The activity of SOD is expressed as units per mg protein and one unit of SOD was defined as the amount of SOD required to inhibit the rate of nitrite production to $50 \%$ at $37^{\circ} \mathrm{C}$.

The concentration of malondialdehyde (MDA) was determined with a MDA Assay Kit A003 (Institute of Biological Engineering of Naijing Jiancheng, Nanjing, China) using the thiobarbituric acid method described by Placer et al. (1966). The principle is that thiobarbituric acid combines with MDA to form a stable pink compound, which can be measured by a colorimetric method (OD at $532 \mathrm{~nm}$ ).

\subsection{Determination of total proteolytic enzyme activity in the midgut of workers}

Fifty newly emerged workers from each colony were color marked on the abdomen and 10-15 of those were removed from each colony 7 days after emergence. The worker bees were first cold anaesthetized, midguts isolated by dissecting, and ten of them were analyzed immediately for protease activities. The midgut samples were homogenized in phosphate buffer solution $(20 \mathrm{mM} ; \mathrm{pH} 7.5)$ at the ratio of $1: 99$ for $30 \mathrm{~s}$, the mixtures centrifuged at 3,000 rpm for $20 \mathrm{~min}$, and the supernatant was used to determine the enzyme activity with Folin phenol reagent using the method described by Lowry et al. (1951).

\subsection{Data calculation and statistical analysis}

All data were subjected to one-way ANOVA using the GLM procedure of SAS (SAS 9.1, SAS Institute 2003). The data were first analyzed as a completely randomized design with individual cage as a random factor to examine the overall effects of treatments. Orthogonal polynomial contrasts were also used to determine linear response of bees to different protein levels of PS. The significance was declared at $P<0.05$.

\section{RESULTS}

Bees consumed more $(P<0.05)$ pollen than PS, whereas all bees in PS treatments had similar food consumption (Table II). In contrast, total protein consumption of the Control (pollen)

Table II. Diet (on dry matter basis) and protein intake protein intake of bees from colonies fed pollen and pollen substitutes ( $N=5$ colonies per treatment).

\begin{tabular}{lrrrrrrrrr}
\hline Item & Control & PS15 $^{\mathrm{a}}$ & PS20 $^{\mathrm{a}}$ & PS25 $^{\mathrm{a}}$ & PS30 $^{\mathrm{a}}$ & PS35 $^{\mathrm{a}}$ & SEM & $\begin{array}{l}P \text { value } \\
\text { (linear) }\end{array}$ \\
\hline $\begin{array}{l}\text { Diet consumption (g/1 frame) } \\
\begin{array}{l}\text { Total protein intake } \\
(\mathrm{g} / 1 \text { frame) }\end{array}\end{array}$ & $127.43 \mathrm{a}$ & $109.34 \mathrm{~b}$ & $104.90 \mathrm{~b}$ & $105.62 \mathrm{~b}$ & $103.42 \mathrm{~b}$ & $102.93 \mathrm{~b}$ & 2.72 & 0.115 \\
& $29.37 \mathrm{~b}$ & $16.60 \mathrm{e}$ & $21.15 \mathrm{~d}$ & $26.77 \mathrm{c}$ & $31.10 \mathrm{~b}$ & $35.97 \mathrm{a}$ & 0.71 & $<0.001$ \\
\hline
\end{tabular}

Means within a row with different letters (a-e) differ significantly $(P<0.05)$.

${ }^{\text {a }}$ PS15, PS20, PS25, PS30, and PS35 were pollen substitutes (PS) containing crude protein (DM basis) at 15\%, 20\%, 25\%, $30 \%$, and $35 \%$. All diets were prepared as patties consisting of $40 \%$ of pollen or one of PS, $50 \%$ sucrose, and $10 \%$ honey. 
group was less than that of PS35 $(P<0.05)$, but more than that of PS25, PS20, and PS15 $(P<$ $0.05)$. Protein consumption of the bees in PS groups linearly increased $(P<0.001)$ as the protein concentration in PS diet increased from $15 \%$ to $35 \%$ and there were significant differences among the five groups.

Percentage of eggs that hatched, percentage of larvae that pupated and weight of newly emerged workers increased linearly $(P \leq 0.05)$ as the protein concentration increased from $15 \%$ to $35 \%$ in PS groups, but the weight of pupa was not varied (Table III). And bees fed pollen (23\% $\mathrm{CP}$ ) had a similar development level to that fed PS20. Workers in PS15 had significantly lower $(P<0.05)$ percentage egg hatch and pupation than those in PS35, and the newly emerged workers had lower weights than those in PS30 $(P<0.05)$.

Effects of different diets on the protein content of newly emerged workers were shown in Figure 1. Workers fed control pollen patty had similar body protein content to that of bees fed PS20, and comparison among the PS groups showed that protein content of newly emerged workers increased linearly $(P<0.01)$ as dietary protein increased. Newly emerged workers fed PS15 had a lower protein content that those fed PS30 $(P<0.05)$ and those fed PS35 were similar to other groups.

Activity of T-SOD was similar among all groups regardless of the treatment (Figure 2a). Concentration of MDA in the bodies of workers in Control group was also similar to that of workers in PS20 groups (Figure 2b). However, body MDA concentration was reduced linearly $(P<0.001)$ as the dietary protein content increased from $15 \%$ to $35 \%$ in PS diet. Workers in PS15 contained the lowest T-SOD activity but the highest MDA content $(P<0.05)$.

Total proteolytic enzyme activity in the midgut of bees were similar to each other among bees fed pollen, PS15, PS20, and PS25, which were all significantly lower $(P<0.001)$ than those fed PS30 and PS35 (Figure 3). Further analysis showed that the enzymatic activity linearly $(P<0.001)$ increased as the dietary protein content increased from $15 \%$ to $35 \%$ in PS.

\section{DISCUSSION}

In this study, we provide experimental evidence for a link between dietary protein and important parameters in honey bees. These results suggest that an adequate provision of protein is required to sustain normal development of bees.

\subsection{Pollen vs. PS}

This study showed that bees consumed significantly more natural pollen than any PS, which is in agreement with other reports (Pernal and Currie 2000; DeGrandi-Hoffman et al. 2010). The higher intake of pollen than that of

Table III. Percentage egg hatch, percentage of pupation, weight of pupa, and weight of newly emerged workers from colonies fed pollen or pollen substitutes ( $N=5$ colonies per treatment).

\begin{tabular}{|c|c|c|c|c|c|c|c|c|}
\hline Item & Control & $\mathrm{PS} 15^{\mathrm{a}}$ & $\mathrm{PS} 20^{\mathrm{a}}$ & $\mathrm{PS} 25^{\mathrm{a}}$ & $\mathrm{PS} 30^{\mathrm{a}}$ & $\mathrm{PS} 35^{\mathrm{a}}$ & SEM & $\begin{array}{l}P \text { value } \\
\text { (linear) }\end{array}$ \\
\hline $\begin{array}{l}\text { Percentage egg } \\
\text { hatch }(\%)\end{array}$ & $85.57 \mathrm{a}, \mathrm{b}$ & $84.12 \mathrm{~b}$ & $85.81 \mathrm{a}, \mathrm{b}$ & $87.94 \mathrm{a}, \mathrm{b}$ & $88.80 \mathrm{a}, \mathrm{b}$ & $92.43 \mathrm{a}$ & 2.15 & 0.006 \\
\hline $\begin{array}{l}\text { Percentage of } \\
\text { pupation }(\%)\end{array}$ & $95.12 \mathrm{a}, \mathrm{b}$ & $93.38 \mathrm{~b}$ & $95.84 \mathrm{a}, \mathrm{b}$ & $96.32 \mathrm{a}, \mathrm{b}$ & $96.58 \mathrm{a}, \mathrm{b}$ & $97.99 \mathrm{a}$ & 1.27 & 0.024 \\
\hline Weight of pupa (g) & 0.128 & 0.126 & 0.127 & 0.130 & 0.138 & 0.129 & 0.004 & 0.140 \\
\hline $\begin{array}{l}\text { Weight of newly } \\
\text { emerged } \\
\text { workers }(g)\end{array}$ & $0.107 \mathrm{a}, \mathrm{b}$ & $0.105 \mathrm{~b}$ & $0.106 \mathrm{a}, \mathrm{b}$ & $0.109 \mathrm{a}, \mathrm{b}$ & $0.115 \mathrm{a}$ & $0.110 \mathrm{a}, \mathrm{b}$ & 0.003 & 0.052 \\
\hline
\end{tabular}

Means within a row with different letters ( $\mathrm{a}$ and $\mathrm{b})$ differ significantly $(P<0.05)$.

${ }^{a}$ PS15, PS20, PS25, PS30, and PS35 were pollen substitutes (PS) containing crude protein (DM basis) at 15\%, 20\%, 25\%, $30 \%$, and $35 \%$. All diets were prepared as patties consisting of $40 \%$ of pollen or one of PS, $50 \%$ sucrose, and $10 \%$ honey. 
Figure 1. The mean concentration of protein in whole bodies $( \pm \mathrm{SE})$ of newly emerged workers from colonies fed pollen and pollen substitutes ( $N=5$ colonies per treatment). Different letters indicate significant differences among the treatments $(P<0.05)$.

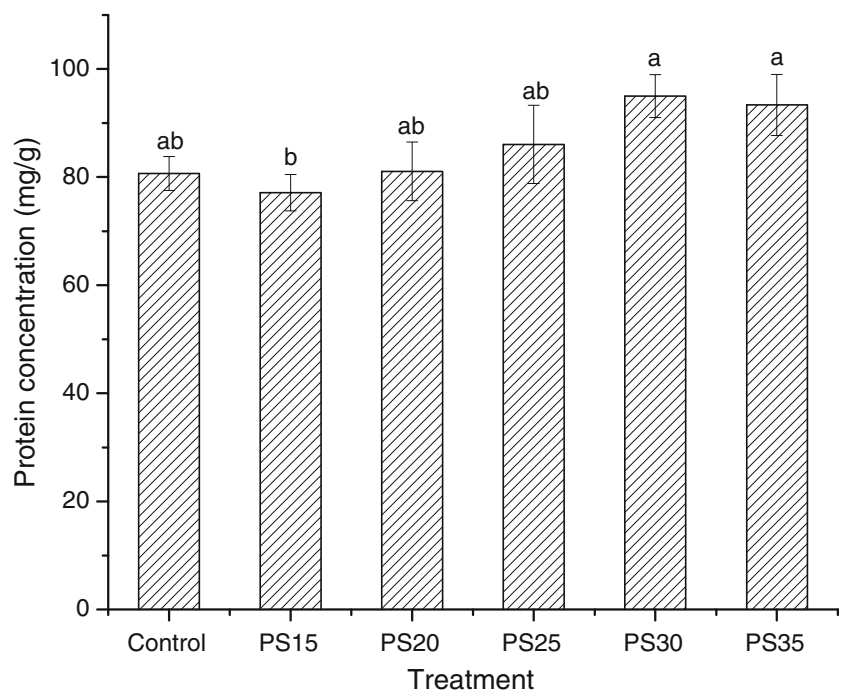

PS is likely due to the fact that pollen was more attractive and palatable to honey bee than PS. Studies have shown that chemicals attractive to honey bees reside in the lipid fraction of the pollenkitt (Dobson 1988).

Surprisingly, greater consumption of pollen did not enhance the development and growth performance of bees. Somerville (2005) revealed that what is probably more important for the growth and development of bees is the total protein intake of a colony but not simply food consumption. In this study, bees consumed significantly more pollen than PS30, but had lower development parameters, although the total protein intakes of these two groups were similar. This might have resulted from the different quantity of protein digested and absorbed since honey bees and bumblebees use proteolytic enzymes to digest dietary protein (Winston 1987; Malone et al. 1998, 2000). And
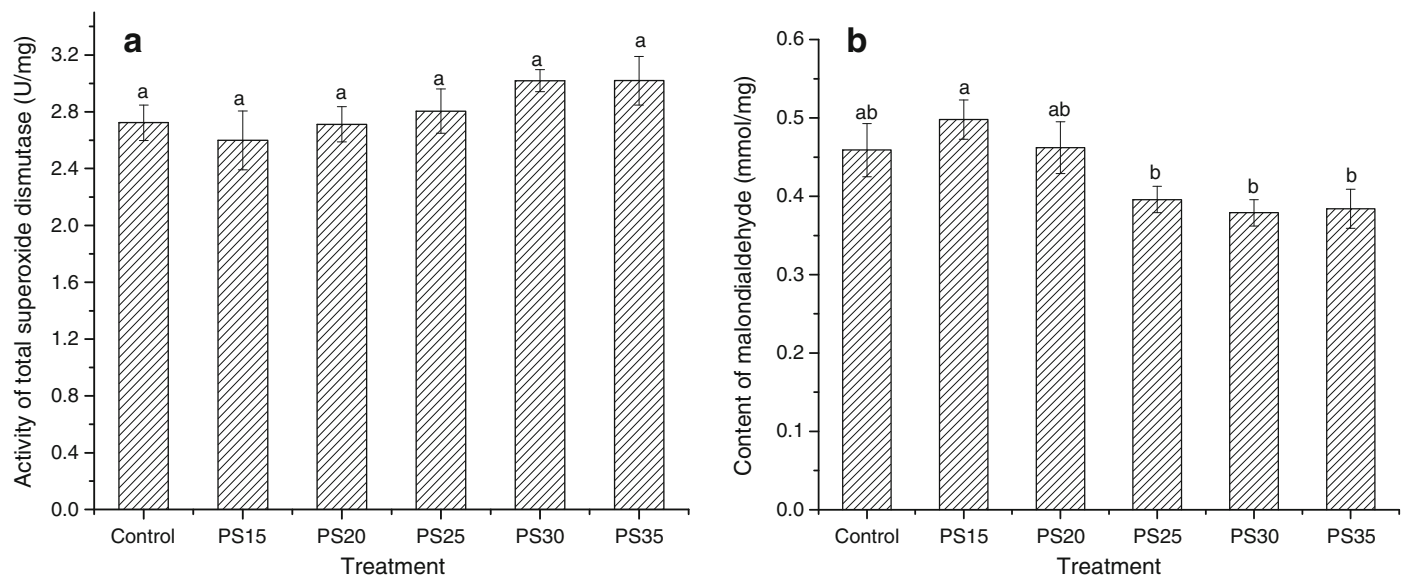

Figure 2. The mean activity of total superoxide dismutase $( \pm \mathrm{SE})$ and content of malondialdehyde $( \pm \mathrm{SE})$ of newly emerged workers from colonies fed pollen and pollen substitutes ( $N=5$ colonies per treatment). Different letters indicate significant differences among the treatments $(P<0.05)$. 
Figure 3. The mean midgut proteolytic enzyme activities of ( \pm SE) 7-day-old bees from colonies fed pollen and pollen substitutes $(N=5$ colonies per treatment) of different concentrations of crude protein. Different letters indicate significant differences among the treatments $(P<0.05)$.

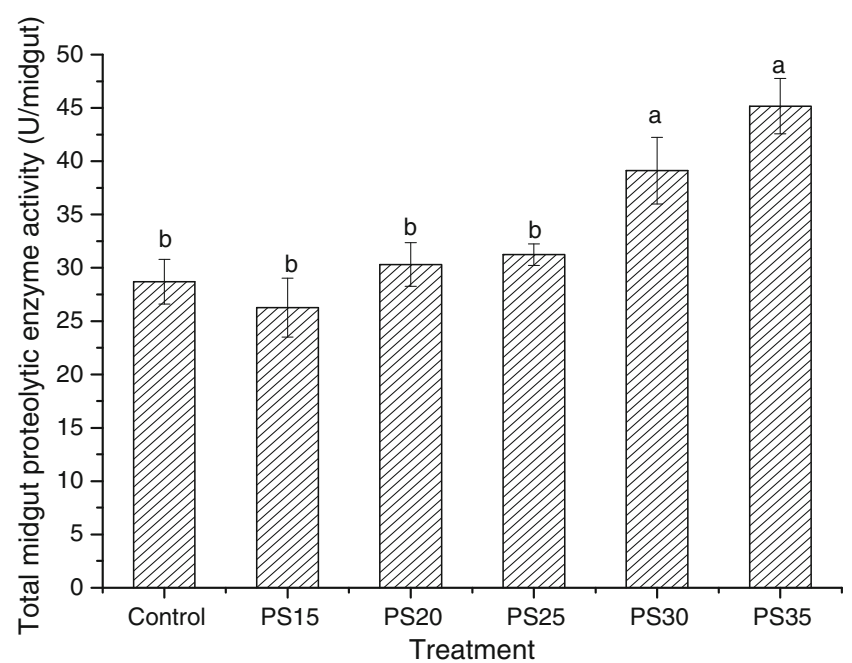

the significantly lower midgut protease activity of bees fed pollen than that of bees fed PS30 supported this explanation exactly.

As there is a linear correction between enzyme activity and substrates, the question arises as to why the midgut protease activity varied between pollen group and PS30. Moritz and Crailsheim (1987) indicated that bees fed on pollen had quite low amounts of soluble protein in the midgut contents, due to the protective wall of the pollen grains (Stanley and Linskens 1974). Therefore, the midgut protease activity of bees fed pollen might be weaker as the soluble protein reduced.

\subsection{Pollen substitutes}

In this experiment, PS diets were consumed in similar amounts even though their CP contents varied from $15 \%$ to $35 \%$. This may partially be due to the fact that all PS diets had similar attractiveness (i.e., visual signal and phagostimulants) to bees. Boch (1982) found a strong correlation between color of pollen and its preference by foraging bees and suggested that the yellow color range was a common visual signal for attracting bees. In this experiment, all PS diets were in the same visual signal range that was comparable to pollen but had no phagostimulant added. Another possible explanation is that the workers may not distinguish the diet quality when the $\mathrm{CP}$ content varied from $15 \%$ to $35 \%$. The results of this study are consistent with that of Schmidt and Johnson (1984) whose work also suggested that food consumption by worker bees was not related to pollen quality (e.g., protein concentration) but influenced by their physical or chemical cues.

Worker bees feed both the queen and the larvae with glandular secretions derived from their food (Schmickl et al. 2003), so egg quality might be influenced by the nutrition the queen received and larva development might be affected by the nutrition the worker provided. The result that significantly more eggs hatched and larvae pupated in colonies fed PS35 compared with PS15 indicates that increasing the dietary content of $\mathrm{CP}$ from $15 \%$ to $35 \%$ enhanced the development of bees. Similar results were obtained by Herbert et al. (1977). They reported that bees fed diets containing $23 \%$ and $30 \%$ protein reared more brood than bees fed diets containing 10\%. All these results emphasized the importance of the amount of protein intake in the growth from egg to imago. Increasing protein intake enhanced the bee development is probably because honey bees need protein for producing cuticle (Campbell 1929; Wigglesworth 1933), muscle, and other tissues (Somerville 2000) while they are growing, and a deficiency of proteins leads to developmental failures (Jay 1963). The second possible explanation is that a lack of dietary protein can reduce 
the immunity in honey bees (Szymaś and Jędruszuk 2003; Alaux et al. 2010). In other words, bees fed inadequate protein diet (PS15) are more susceptible to disease (Mattila and Otis 2006) and result in significantly lower survival rate (Jay 1964). In this study, pupal weight was not affected by dietary protein content, but there was a tendency for bees consuming PS30 to grow faster during the pupal phase as compared with bees fed the other diets. In addition, diet containing 30\% CP increased the weight and protein contents of newly emerged workers. These results are consistent with other reports that showed that dietary protein level affected bees' body size (Ribeiro 1994; Nguyen 1999; Roulston and Cane 2002). Levin and Haydak (1951) also observed that the weight of honey bees at emergence was affected by the nutritional status of a colony and pattern of nutrient supply. Therefore, weight of emerging bees would be a reliable parameter assessing the nutritional status of a colony. Measurement protein content (especially hemolymph protein concentration) in honey bees is an effective method for the evaluation of protein diet quality (Cremonez et al. 1998; De Jong et al. 2009). Schmickl and Crailsheim (2001) showed that colonies experiencing protein shortage produced workers that had slightly reduced levels of protein. Inadequate pollen diet can lower worker nitrogen content (Duff and Furgala 1986, although effects were lacking in some years). It is therefore reasonable to conclude that there is a robust association between dietary protein content and worker protein content. In order to evaluate the diet efficiency precisely, we tested the total protein content in newly emerged workers. Bees fed PS15 diet had lower body protein concentration than bees fed PS30 and PS35 diet although it was similar to other treatments, indicating that protein level in PS15 diet was not supportive for the optimum growth and development of bees. This is consistent with other growth and physiological parameters measured in this study (e.g., percentage egg hatch, percent of pupation and antioxidant status, etc.).

All aerobic organisms generate reactive oxygen species in the process of their oxidative metabolism (Felton and Summers 1995; Michiels et al. 1994). The reactive oxygen species can cause many destructive reactions contributed to the processes of aging and cell death. To protect against the effects of "oxidative stress," organisms have a variety of antioxidant enzyme present in the biological system. Among others, the SOD enzymes are recognized as being the most important antioxidant enzymes in scavenging the oxygen free radical. Malondialdehyde is formed as an end product of lipid peroxidation and therefore the extent of lipid peroxidation by reactive oxygen species can be monitored by MDA levels (Sumida et al. 1989). The lower MDA concentration of bees fed PS25, PS30 and PS35 than for bees fed PS15 indicated that bee antioxidant status was improved by increasing dietary protein content from $15 \%$ to $35 \%$ and therefore lipid peroxidation was reduced. The inferior antioxidant status of bees fed PS15 to those fed PS25, PS30, and PS35 also suggests that dietary protein at $15 \%$ by dry matter does not support the optimum physiology of bees. The observation that MDA concentration was reduced even though T-SOD activity was not affected by dietary protein concentration is probably explained by alterations in other antioxidant enzyme activities, such as glutathione $S$-transferase, glutathione peroxidase, and glutathione reductase, which also exist in insects (Ahmad et al. 1991; Joanisse and Storey 1996). Further research is needed in this area.

The higher midgut protease activity of bees fed the diet with $30 \%$ and $35 \%$ CP than those of bees fed other PS diets indicated that these groups of bees not only ate more protein but also digested and absorbed more protein than others. A highly significant correlation of some enzymes activities to protein content in midgut has been previous reported (Moritz and Crailsheim 1987). Therefore, the higher levels of proteolytic enzymes activity in bees fed diet containing more protein is likely due to the greater amount of protein intake in these groups of bees. This result quite explains the phenomena that bees fed PS30 and PS35 had enhanced growth and physiological parameters measured in this study and supports the hypothesis of De Grandi-Hoffman et al. (DeGrandi-Hoffman et al. 
2008) that perhaps the digestibility and accessibility of diet nutrients to worker bees influence the colony status even when consumption rates are similar.

\section{CONCLUSIONS}

Our study indicates that the PS used appeared to be a valuable proteinaceous food and provision of adequate dietary protein to a colony will improve brood rearing, weight of individual bees, body protein content, and antioxidant status of emerging workers. In this study, PS with a protein level about 30 35\% were recognized as an excellent diet for promoting bee development. These findings are particularly important for the successful beekeeping (management of colonies) using PS when natural pollen is unavailable.

\section{ACKNOWLEDGMENTS}

We thank staff apiarist G. L. Zhang and students F. Liu, B. L. Zheng, Z. Jiao, G. Y. Wang, Y. J. Li, Y. Wang, L. T. Ma, Z. F. Wu, Y. D. Zhang, G. Zhang, and $\mathrm{X}$. B. Hang for assistance with data collection. We express our cordial thanks to Y. Wang and P. Liu for the linguistic correction of our paper. This research was financially supported by the earmarked fund for Modern Agro-industry Technology Research System (CARS-45) and Special Fund for Agro-scientific Research in the Public Interest (no. 200903006).

Effets de différents niveaux de protéines d'origine alimentaire sur le développement, le statut antioxidant et l'activité protéasique de l'intestin moyen des abeilles (Apis mellifera ligustica)

Apis mellifera ligustica / protéine d'origine alimentaire / développement/antioxydant / activité protéasique / intestin moyen

Effekte des Gesamptproteingehalts in der Nahrung auf die Entwicklung, den Antioxidanz-Status und die Gesamtproteaseaktivität im Mitteldarm von Honigbienen (Apis mellifera ligustica)

Apis mellifera ligustica / Nahrungsgesamtproteingehalt / Entwicklung / Antioxidanz-Status / Mitteldarmgesamtproteaseaktivität

\section{REFERENCES}

Ahmad, S., Duval, D.L., Weinhold, L.C., Pardini, R.S. (1991) Cabbage looper antioxidant enzymes: tissue specificity. Insect Biochem. 21, 563-572

Alaux, C., Ducloz, F., Crauser, D., Le Conte, Y. (2010) Diet effects on honeybee immunocompetence. Biol. Lett. 6, 562-565

Arking, R., Burde, V., Graves, K., Hari, R., Feldman, E., Zeevi, A. (2000) Forward and reverse selection for longevity in Drosophila is characterized by alternation of antioxidant gene expression and oxidative damage patterns. Exp. Gerontol. 35, 167-185

Boch, R. (1982) Relative attractiveness of different pollens to honeybees when foraging in a flight room and when fed in the hive. J. Apic. Res. 21, 104-106

Burgess, E.P.J., Malone, L.A., Christeller, J.T. (1996) Effects of two proteinase inhibitors on the digestive enzyme. J. Insect Physiol. 42, 823-828

Campbell, F.L. (1929) The detection and estimation of insect chitin; and the relation of "chitinization" to hardness and pigmentation of the cuticula of the American cockroach, P. americana. Ann. Entomol. Soc. Am. 22, 401-440

Chen, S.L. (2001) The apicultural science in china. China Agricultural Press, Beijing

Cremonez, T.M., De Jong, D., Bitondi, M.M.G. (1998) Quantification of hemolymph protein as a fast method for testing protein diets for honey bees (Hymenoptera: Apidae). J. Econ. Entomol. 91, 1284-1289

De Jong, D., da Silva, E.J., Kevan, P.G., Atkinson, J.L. (2009) Pollen substitutes increase honey bee haemolymph protein levels as much as or more than does pollen. J. Apic. Res. 48, 34-37

DeGrandi-Hoffman, G., Wardell, G., Ahumada-Segura, F., Rinderer, T., Danka, R., Pettis, J. (2008) Comparisons of pollen substitute diets for honey bees: consumption rates by colonies and effects on brood and adult populations. J. Apic. Res. 47, 265-270

DeGrandi-Hoffman, G., Chen, Y.P., Huang, E., Huang, M.H. (2010) The effect of diet on protein concentration, hypopharyngeal gland development and virus load in worker honey bees (Apis mellifera L.). J. Insect Physiol. 56, 1184-1191

Dietz, A. (1969) Initiation of pollen consumption and pollen movement through the alimentary canal of newly emerged honeybees. Ann. Entomol. Soc. Am. 62, 43-46

Dobson, H.E.M. (1988) Survey of pollen and pollenkitt lipids-chemical cues to flower visitors. Am. J. Bot. 75, 170-182

Doull, K.M. (1973) Relationship between pollen, brood rearing and consumption of pollen supplements by honeybees. Apidologie 4, 285-293 
Duff, S.R., Furgala, B. (1986) Pollen trapping honey bee colonies in Minnesota: part II: effect on foraging activity, honey production, honey moisture content, and nitrogen content of adult workers. Am. Bee J. 126, 755-758

Felton, G.W., Summers, C.B. (1995) Antioxidant systems in insects. Arch. Insect Biochem. Physiol. 29, 187-197

Flores, J.M., Gutiérrez, I., Espejo, R. (2005) The role of pollen in chalkbrood disease in Apis mellifera: transmission and predisposing conditions. Mycologia 97, 1171-1176

Gilliam, M., Taber, S., Richardson, G. (1983) Hygienic behavior of honey bee in relation to chalkbrood disease. Apidologie 14, 29-39

Hagedorn, H.H., Moeller, F.E. (1967) The rate of pollen consumption by newly emerged honeybees. J. Apic. Res. 6, 159-162

Haydak, M.H. (1970) Honey bee nutrition. Ann. Rev. Entomol. 15, 143-156

Herbert, E.W., Shimanuki, H. (1982) Effect of population density and available diet on the rate of brood rearing by honey bees offered a pollen substitute. Apidologie 13, 21-28

Herbert, E.W., Shimanuki, H., Caron, D. (1977) Optimum protein levels required by honey bees (Hymenoptera: Apidae) to initiate and maintain brood rearing. Apidologie 8, 141-146

Hornitzky, M. (2010) Honey bee diseases, Australia and New Zealand Standard Diagnostic Procedure 2003. Available at: www.scahls.org.au/procedures/anzsdp

Jay, S.C. (1963) The development of honeybees in their cells. J. Apic. Res. 2, 117-134

Jay, S.C. (1964) Starvation studied of larval honey bees. Can. J. Zool. 42, 455-462

Joanisse, D.R., Storey, K.B. (1996) Oxidative stress and antioxidants in overwintering larvae of cold-hardy goldenrod gall insects. J. Exp. Biol. 199, 1483-1491

Knox, D.A., Shimanuki, H., Herbert, E.W. (1971) Diet and the longevity of adult honey bees. J. Econ. Entomol. 64, 1415-1416

Levin, M.D., Haydak, M.H. (1951) Seasonal variation in weight and ovarian development in the worker honeybee. J. Econ. Entomol. 44, 54-57

Lowry, O., Rosebrough, N., Farr, A., Randall, R. (1951) Protein measurement with the Folin phenol reagent. J. Biol. Chem. 193, 365-275

Malone, L.A., Burgess, E.P.J., Christeller, J.T., Gatehouse, H.S. (1998) In vivo responses of honey bee midgut proteases to two protease inhibitors from potato. J. Insect Physiol. 44, 141-147

Malone, L.A., Burgess, E.P.J., Stefanovic, D., Gatehouse, H.S. (2000) Effects of four protease inhibitors on the survival of worker bumblebees (Bombus terrestris L.). Apidologie 31, 25-38
Mattila, H.R., Otis, G.W. (2006) Influence of pollen diet in spring on development of honey bee (Hymenoptera: Apidae) colonies. J. Econ. Entomol. 99, 604-613

Michiels, C., Raes, M., Toussaint, O., Remacle, J. (1994) Importance of Se-glutathione peroxidase, catalase, and $\mathrm{Cu} / \mathrm{Zn}-\mathrm{SOD}$ for cell survival against oxidative stress. Free Radical Biol. Med. 17, 235-248

Moritz, B., Crailsheim, K. (1987) Physiology of protein digestion in the midgut of the honeybee (Apis mellifera L.). J. Insect Physiol 33, 923-931

Nguyen, V.N. (1999) Effect of protein nutrition and pollen supplementation of honeybee, Apis mellifera L. colonies on characteristics of drones with particular reference to sexual maturity. Aust. Beekeeper (Mar) 101, 374-376

Oyanagui, Y. (1984) Reevaluation of assay methods and establishment of kit for superoxide dismutase activity. Anal. Biochem. 142, 290-296

Pernal, S.F., Currie, R.W. (2000) Pollen quality of fresh and 1-year-old single pollen diets for worker honey bees (Apis mellifera L.). Apidologie 31, 387-409

Phillips, J.P., Campbell, S.D., Michaud, D., Charbonneau, M., Hilliker, A.J. (1989) Null mutation of copper/zinc superoxide dismutase in Drosophila confers hypersensitivity to paraquat and reduced longevity. Proc. Natl. Acad. Sci. (USA) 86, 2761-2765

Placer, Z.A., Cushman, L.L., Johnson, B.C. (1966) Estimation of production of lipid peroxidation, malindialdehyde in biochemical system. Anal. Biochem. 16, 359-367

Ribeiro, M. (1994) Growth in bumble bee larvae: relation between development time, mass, and amount of pollen ingested. Can. J. Zool. 72, 1978-1985

Rothenbuhler, W. (1964) Behavior genetics of nest cleaning in honey bees. I. Response of four inbred lines to disease-killed brood. Anim. Behav. 12, 578-583

Roulston, T.H., Cane, J.H. (2002) The effect of pollen protein concentration on body size in the sweat bee Lasioglossum zephyrum (Hymenoptera: Apiformes). Evol. Ecol. 16, 49-65

SAS Institute. 2003. SAS/STAT User's Guide: version 9.1 th edn

Schäfer, M.O., Dietemann, V., Pirk, C.W.W., Neumann, P., Crewe, R.M., Hepburn, H.R., Tautz, J., Crailsheim, K. (2006) Individual versus social pathway to honeybee worker reproduction (Apis mellifera): pollen or jelly as protein source for oogenesis. J. Comp. Physiol. A 192, 761-768

Schmickl, T., Crailsheim, K. (2001) Cannibalism and early capping: strategy of honeybee colonies in times of experimental pollen shortages. J. Comp. Physiol. A 187, 541-547

Schmickl, T., Blaschon, B., Gurmann, B., Crailsheim, K. (2003) Collective and individual nursing investment 
in the queen and in young and old honeybee larvae during foraging and non-foraging period. Insect Soc. 50, 174-184

Schmidt, J.O., Johnson, B.E. (1984) Pollen feeding preference of Apis mellifera, a polylectic bee. Southwest. Entomol. 9, 41-47

Schmidt, J.O., Thoenes, S.C., Levin, M.D. (1987) Survival of honey bees, Apis mellifera (Hymenoptera: Apidae), fed various pollen sources. Ann. Entomol. Soc. Am. 80, 176-183

Schmidt, L.S., Schmidt, J.O., Hima, R., Wang, W.Y., Xu, L.G. (1995) Feeding preference and survival of young worker honey bees (Hymenoptera: Apidae) fed rape, sesame, and sunflower pollen. J. Econ. Entomol. 88, 1591-1595

Somerville, D. (2000) Honey bee nutrition and supplementary feeding, Agnote DAI/178, NSW Agriculture

Somerville, D. (2005) Fat bees skinny bees-a manual on honey bee nutrition for beekeepers. Publication no. 05/054. A report for the Rural Industries Research and Development Corporation, Barton

Somerville, D.C., Nicol, H.I. (2006) Crude protein and amino acid composition of honey bee-collected pollen pellets from south-east Australia and a note on laboratory disparity. Aust. J. Exp. Agr. 46, 141-149

Spivak, M., Reuter, G.S. (2001) Resistance to American foulbrood diseases by honey bee colonies Apis mellifera bred for hygienic behavior. Apidologie 32, 555-565

Stanley, R.G., Linskens, H.F. (1974) Pollen: biology, biochemistry, management. Springer, Berlin

Sumida, S., Tanaka, K., Kitao, H., Nakadomo, F. (1989) Exercise induced lipid peroxidation and leakage of enzyme before and after vitamin E supplementation. Int. J. Biochem. 21, 835-838

Szymaś, B., Jędruszuk, A. (2003) The influence of different diets on haemocytes of adult worker honey bees, Apis mellifera. Apidologie 34, 97-102

Wigglesworth, V.B. (1933) The physiology of the cuticle and of ecdysis in Rhodnius prolixus (Triatomidae, Hemiptera); with special reference to the function of the oenocytes and of the dermal glands. Quart. J. Microsc. Sci. 76, 269-318

Winston, M.L. (1987) The biology of the honey bee. Harvard University Press, Cambridge 